\title{
The Middle Income Trap: Theory and Empirical Evidence
}

\author{
Mehmet Hanefi TOPAL* \\ Gümüşhane University
}

\begin{abstract}
The middle income trap (MIT) is a concept that is often used in the economic development literature but is not defined clearly enough. The purpose of this study is to revise previous discussions on MIT and to make an empirical investigation of the existence of MIT in 44 middle-income countries based on Ye and Robertson's (2016) time series approach. Unlike conventional time series analyses, this study takes into consideration non-linearity in time series and smooth transition of structural breaks. The empirical findings of this study show the following results. There is strong evidence of the existence of MIT in seven countries. The stochastic convergence is valid for twenty one countries, including Turkey. The trend findings of the countries show that the income gap between ten countries and the US is decreasing quite slowly or increasing steadily. These results also indicate that economic and institutional reform requirements maintain their priority in the political agenda in most middle income - especially in Latin American- countries.
\end{abstract}

Keywords: Middle income trap, economic development, convergence, time series analysis JEL Classification: 010, 040, 047

\section{Orta Gelir Tuzağı: Teori ve Ampirik Kanıt}

\begin{abstract}
Özet
Orta gelir tuzağı, iktisadi kalkınma literatüründe sıklıkla kullanılan ancak yeterince açıklığa kavuşturulamamış kavramlardan biridir. Bu çalışmanın amacı; OGT üzerine yapılmış daha önceki tartışmaları yeniden gözden geçirmek ve Ye ve Robertson'un (2016) zaman serileri yaklaşımından hareketle 44 orta gelirli ülkede OGT varlığını ampirik olarak incelemektir. Geleneksel zaman serisi analizlerinden farklı olarak bu çalışmada zaman serilerinde doğrusal olmama ve yapısal kırılmaların yumuşak geçişli olması durumları dikkate alınmıştır. Bu çalışmanın ampirik bulguları şu sonuçları ortaya koymaktadır. 7 ülke için MIT'in varlığına dair güçlü kanıtlar belirlenmiştir. Türkiyenin de dâhil olduğu 21 ülke için stokastik yakınsama anlamlıdır. Ülkeler için trend bulguları 10 ülke ile ABD arasındaki gelir açı̆̆ının çok yavaş kapanmakta olduğunu ya da gelir açığının sürekli büyümekte olduğunu göstermektedir. Bu sonuçlar orta gelirli ülkelerin çoğunda -özellikle Latin Amerika ülkelerinde- ekonomik ve kurumsal reform gerekliliklerinin politik ajandadaki önceliğini halen korumaya devam ettiğini de ortaya koymaktadır.
\end{abstract}

Anahtar Kelimeler: Orta gelir tuzağı, ekonomik kalkınma, yakınsama, zaman serisi analizi. JEL Sinıflandirmasi: O10, O40, O47.

\footnotetext{
* Mehmet Hanefi Topal is an Associate Professor in the Department of Public Finance at Gumushane University, Bağlarbaşı Mah. Merkez, Gümüşhane, Turkey. E-mail: mhtopal@ @umushane.edu.tr. ORCID: 00000003-4014-8694

** I would like to express my great thanks to the Editor and two anonymous reviewers for their very useful comments on this study.
} 
$\mathrm{T}$

The middle income trap (MIT) has been one of the most controversial topics in the economic literature and political agendas in recent years. In general, the concept of MIT refers to the state of a country that reaches the status of a middle income country at the end of a rapid growth process but fails to catch up with developed countries by staying in the middle income range (hereafter MIR) for a long time (Glawe \& Wagner, 2016, pp. 508-509). The concept was introduced to the literature with a World Bank report entitled "An East Asian Renaissance: Ideas for Economic Growth" prepared by Gill and Kharas (2007). The report explains the reason for the slowdown in Eastern Asian (EA) economies following a rapid economic growth process. With their study entitled "What Is the Middle Income Trap, Why Do Countries Fall into It, and How Can It Be Avoided?” Kharas and Kohli (2011) made MIT debates popular a few of years after the World Bank report. After these articles, several studies highlighted the need for countries in MIT to make extensive political and economic structural reforms in order to overcome this trap and achieve sustainable development (among others Woo, 2009; Ohno, 2009; Kharas and Kohli, 2011; Reisen, 2011; Aoki, 2012; Woo et al, 2012; Tho, 2013; Gill \& Kharas, 2015).

Similarly, in recent years, there has been a considerable escalation in the number of empirical studies that focus on which middle-income countries (hereafter MICs) are in MIT (e.g., Eichengreen et al., 2012; Woo et al., 2012; Felipe et al., 2012; Hout, 2014; Kharas \& Kohli, 2011; Aiyar et al., 2013; The World Bank, 2013). However, the findings of these studies are mostly based on informal and descriptive evidence. Also, these studies fail to explain whether growth slowdown results from income convergence or the trap itself. Unlike these studies, Ye and Robertson (2016) developed a corresponding standpoint that is consistent with the idea of income convergence and constructed on an empirical definition of MIT. The authors defined countries as MICs whose GDPs per capita are $40 \%$ of that of the US, the reference country. The authors classify a country as in a MIT when its relative per capita income is time invariant to and stand in range of 8-36\% of the reference country (US) GDP per capita.

The aim of this study is to examine previous theoretical discussions and empirical evidence concerning MIT and, in order to determine the countries in MIT, to investigate the states of 44 MICs relative to MIT within the framework of the convergence approach adopted by Ye and Robertson (2016). To analyze the existence of MIT for 44 MICs, the present study extends the authors' time series approach to new generation estimation methods. In this regard, this paper brings the following contributions to the current literature. First, Ye and Robertson (2016)'s study employed linear unit root tests when studying the existence of stochastic convergence. This study investigates the validity of stochastic convergence by considering the linearity or non-linearity of countries' economic time series. Second, this study took into consideration one or two structural breaks for certain countries. Even though Ye and Robertson (2016) applied unit root tests based on the assumption that structural breaks have a sharp transition, in this study structural breaks are modelled by Fourier approximation. With this in mind, structural breaks are assumed to have a smooth transition and the number of structural breaks are endogenously determined. Accordingly, the present study employs more robust estimation methods in order to avoid biased results stemming from modeling mistakes.

This paper is organized as follows. Section one presents the most common theoretical discussions on the definition of MIT, its reasons, and requirements for avoiding MIT. Section two provides a brief literature review of the results of empirical research aimed at empirically defining MIT and determining MICs in MIT. Section three introduces the methodology of the convergence and time series analyses applied in this study. Section four reports the empirical findings. The conclusion involves an evaluation of the results obtained from theoretical discussions and empirical analyses. 


\section{Theoretical Background}

Explaining MIT is actually about understanding the link between the concepts of "trap" and "middle income". Fundamentally, the term "trap" is a concept that has been used for a long time in the economic development literature in order to explain the poverty trap of low-income countries (LICs). In its simplest form, this concept defines a state of economic equilibrium that cannot be changed by short-run external factors (Chai, 2012: 51). If one wishes to go into further detail, it is possible to talk about the three distinctive features of the trap: selfproceeding or self-strengthening process, struggle of breaking away from that process, and insistent character (Glave \& Wagner, 2016: 512). In particular, the third feature is used to explain MIT as the common attribute of countries caught in MIT is their insistence on the failure to implement structural reforms helping them evade the trap (Kharas \& Kohli, 2011; Chai, 2012; Jankowska, et al., 2012; Im \& Rosenblatt, 2015).

The attempts to define MIT can be divided into two groups. The first one is the theoretical definition of MIT. While defining MIT, the focus is on the institutional and political regulations required for the country to get out of the MIR. MIT is considered to be the result of failure to implement institutional and structural reforms or, in brief, a sort of policy failure (Kharas \& Kohli, 2011; Jankowska et al., 2012). According to this definition, MICs in MIT are those countries that are unable to compete with the manufacturing exports of LICs based on low wages and the quality products and innovations of developed economies and are stuck between the two groups (Gill \& Kharas, 2007: 4-5). Reaching the middle income level following a rapid economic growth process, these countries generally get stuck in the middle income level as they are not able to actualize the changes aimed at the diversification of industrial products, capability of producing products with high added value, skilled labor, and amelioration of economic, social, and institutional capacity (Agenor \& Cauto, 2012; Kritayanavaj et al., 2012; Flaaen et al., 2013; Gill \& Kharas, 2015).

Distinctively, the second group of MIT definition is quantitative or empirical. According to Glawe and Wagner (2016), definitions of this group can be divided into two subgroups as absolute and relative approaches. The absolute approach depends on precise and clear middle-income thresholds. It is used most frequently to separate countries using the four income groups ${ }^{[1]}$ based on income per capita and calculated by the Atlas method of the World Bank (Aiyar et al., 2013; Felipe et al., 2012; Hout, 2014; Im \& Rosenblatt, 2015, the World Bank, 2016). By contrast, according to the relative approach, MIT thresholds are the ratio of income per capita of the country to the national income of the country at the steady-state GDP per capita level like US or Japan (e.g. Woo et al., 2012; Ye \& Robertson, 2016). However, the different definitions of income thresholds or relative income rate ranges within the scope of different studies and the use of different GDP datasets in empirical analyses have resulted in the emergence of many quantitative MIT definitions in the literature.

Some authors explain the growth slowdowns and the ensuing trapping of countries by attempting to comprehend the background dynamics of these processes. In the literature, there are many theoretical approaches trying to clarify MIT within this context. Among these approaches, population theory of Malthus is useful while explaining why a country experiences growth slowdown followed by a poverty trap but it is inadequate for the clarification of MIT. According to Malthus, as GDP per capita increases, the population increases, the death rate decreases, and the growth rate slows down due to the decreasing marginal productivity, all of which lead to a poverty trap. Yet MIT is not a poverty trap; it is a state encountered by countries

\footnotetext{
${ }^{[1]}$ These income thresholds are as follows: \$1,025 or less (low-income countries), \$1,026-4,035 (lower-MICs), \$4,036-12,475 (upper-MICs), and \$12,476 and above (high-income countries) (The World Bank, 2016).
} 
that are able to escape from the poverty trap and to reach middle-income levels due to rapid growth rates but then get stuck in a development trap and render it unable to escape from MIR (Aoki, 2011; Koçak and Bulut, 2014).

Another view explaining economic growth slowdowns is the classical economic approach. Lewis (1954) made the first attempt to explain growth slowdowns within the context of this approach. According to Lewis's two-sector development model (1954), the main source of growth is structural change. The high growth rate in the beginning of development is about productivity gains. The increase of development depends on the transfer of capital and labor from the unproductive agriculture to the productive manufacturing (Gill \& Kharas, 2015). On the other hand the neoclassical view focuses on comparative advantages in trade. According to this view, if the country manages to specialize in labor-intensive and low-wage jobs in the first stage of development and adapt the high technology of developed countries to its production processes, it can grow fast by gaining the comparative advantage in international competition (Barro \& Sala-i Martin, 1997). However, this adaptation is not a continuous process. Productivity gains arising from resource allocation will eventually slow down over time, unemployment and real wages will increase, and the export advantage of the country will disappear. Furthermore, revenue increases stemming from technology transfers of the country will also wane. Basically, the growth slowdown is about the weakening of the international competitive power (Agenor et al., 2012; Öz, 2012; The World Bank, 2013). In order for the economy to get itself out of the situation signifying entrapment in MIT, political and institutional regulations are mostly suggested. Within this context, the necessity of MIT countries to shift from a reallocation, investment, and imitation-oriented growth strategy to an innovation-oriented growth strategy is emphasized (Acemoglu et al., 2006; Aghion \& Howitt, 1992). Distinctly, in their mathematical model focusing on Argentina, Dabus et al. (2016) claimed that countries need to make changes in external conditions to maintain their comparative advantages.

Another theoretical approach explaining growth slowdown within the context of productivity decreases was put forward by Agenor and Cauto (2012). According to their overlapping generation model, there are three basic identifiers of productivity: individual decision-making that helps to gain skills, access to different types of infrastructure, and information network externalities. Scholars make a distinction between two types of infrastructures: basic and information-communication technologies, along with between two types of skills: basic and high-level skills. Diffusion of information and the impacts of learning by practice bear importance for productivity increases. MIT is associated with infrastructure inadequacy and the false positioning of skills. In many studies, scholars also underline the significance of accurate allocation processes taking the interdependence of education and innovation, human capital, and technology investments for releasing oneself from MIT.

A number of researchers (e.g., Ohno, 2009; Aoki, 2012; Tho, 2013) have attempted to explain MIT by particularly focusing on Asian economies, similar to W. W. Rostow's (1990) popular development stages approach. The first scholar to be discussed here is Ohno (2009) who explained the transition from poverty to advanced development with a five-stage development model in research on the countries within the Association of Southeast Asian Nations (ASEAN). The transition from one stage to the next depends on the extent to which the requirements for this transition are fulfilled. Figure 1 shows the development stages and the requirements for reaching the later stages. 
Figure 1 The Stages of Economic Development

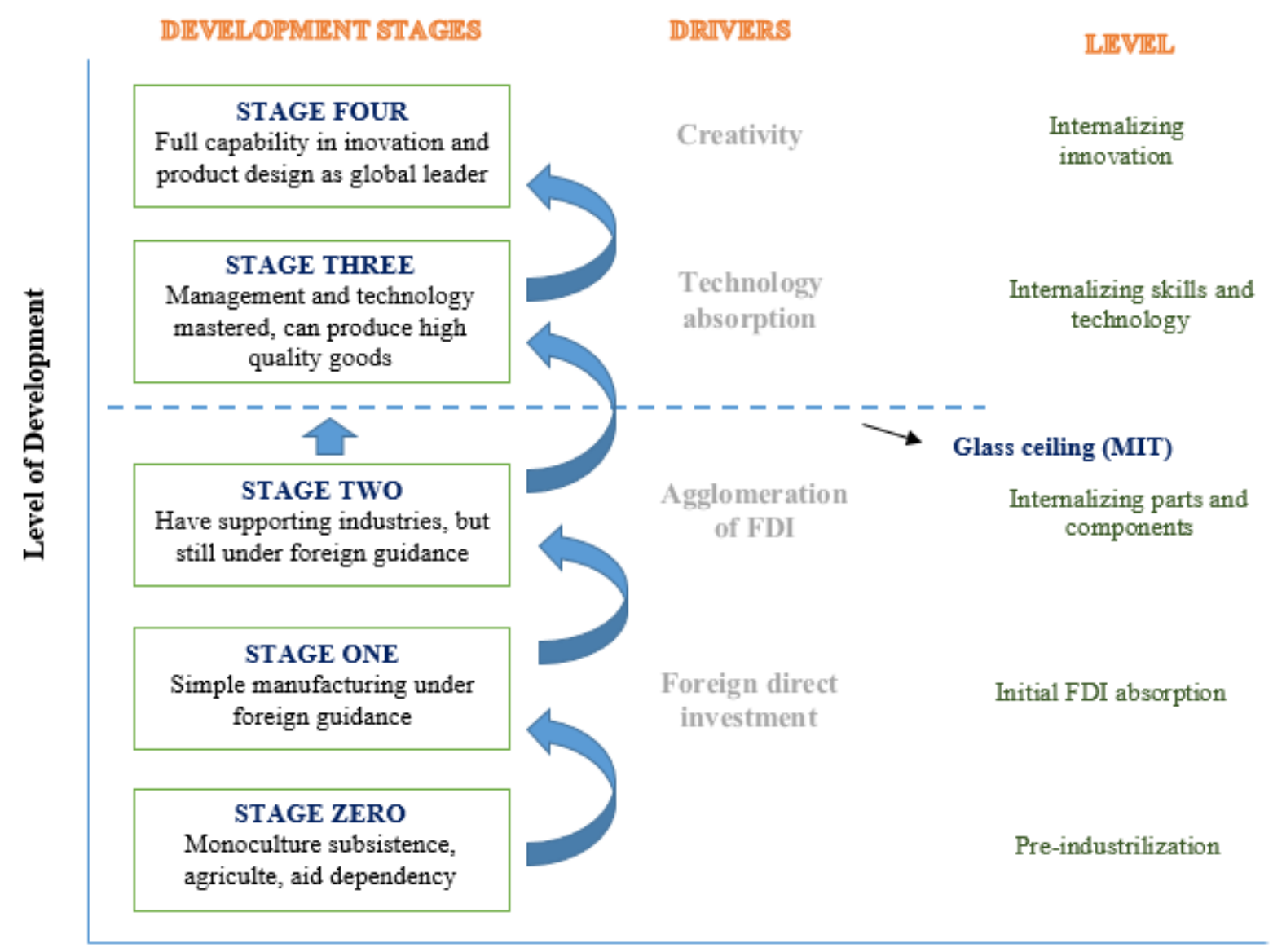

Source: Ohno (2009)

In Stage Zero (the beginning), countries face war, political tensions, poor economic governance, and a fragile infrastructure. Economic prosperity depends on monoculture exports, subsistence agriculture, and external aids. The transition from this stage to Stage One (i.e. getting out of the poverty trap) requires attracting foreign direct investments in the country. In Stage One, the added value gained from mining and agricultural sectors is low, and industrialization is dependent on external sources. Design, production, marketing, and technology sectors are mostly dominated by foreigners. The expansion of the industrial area, privatization, deregulation, and the creation of favorable working spaces are important for the transition to Stage Two. In Stage Two, the concentration of production is complete; the local suppliers have, although weak, competitive capabilities; and the potential of internal added value is increased. However, simple production sectors are dominated by local firms while key sectors are still dominated by foreigners. In the economy, wages increase while factor productivity decreases. In particular, the country reaching the middle-income level with the help of foreign capital is stuck in the development trap due to an invisible "glass ceiling". The knowledge and skills of foreign partners are not sufficient on their own in order for the country to attain a high-income level. They also need to be internalized with high human capital accumulation. In Stage Three, external dependence and the domination of foreigners over the key sectors are significantly diminished while national capital has become paramount. The human capital accumulation of the country has increased and local products have high competitive power in international markets. A country in Stage Three needs to attach importance to $\mathrm{R} \& \mathrm{D}$ and technology investments as well as innovative products in order to 
reach the countries at the final level that has achieved advanced specialization and promotion through creative products in the global market.

Concentrating on China, South Korea, and Japan, Aoki (2012) also explained MIT with a five-stage development model. The first development stage is the Malthusian poverty trap (M) stage. In this stage, the income level of the country is low, growth is stagnant, and the majority of the labor force $(>80 \%)$ is employed in the agricultural sector. The second stage is the government leadership stage $(\mathrm{G})$. In this stage, the government is included in the process of accumulating industrial capital, but the growth rate and structural change are quite slow. The third stage is the Kuznets stage (K). In this stage, the development process goes through a rapid structural transformation. Employment shifts from agriculture to manufacturing. The fourth stage is the human capital-based development stage $(\mathrm{H})$ within the scope of which human capital stock is increased through the improvement of health conditions, low fertility rates, and high education levels. The sustainability of growth depends on the total factor productivity and investments in human capital. The fifth stage is the post-demographic transition stage (PD). In this stage, economic growth relies on technological, socioeconomic, and demographic changes. According to Aoki (2012), countries in MIT are those who have failed the transition from Stage $\mathrm{K}$ to Stage $\mathrm{H}$.

Using a similar approach and starting from the experiences of Asian countries, Tho (2013) explained MIT with a three-stage development process. The first stage signifies the poverty trap and underdevelopment; the second stage is the escaping from the poverty trap and its final point represents the middle-income upper bond; the third stage indicates the sustainable growth required for development. A country stuck in the second stage is defined as a MIT country. Fundamentally reaching a MIC level is also a long journey for underdeveloped countries. In order to do so, a country must shift from an agriculture-oriented economic structure toward an industry and/or services-based economic structure. Extensive structural reforms covering the factor market, technology level, and comparative advantage must be implemented for an underdeveloped economy to reach the middle-income level. Economies reaching the middle-income level but losing their competitive advantages due to the decrease in factor productivity and the increase in wages are stuck in the MIT. If these countries are to reach high-income levels, they need to move toward an innovative economic order supported by high human capital and technological transformation. Within this context, structural reform measures covering technological structure, administrative resources, and skilled labor transformations bear great importance.

\section{Literature Review}

Apart from theoretical models and approaches concerning MIT, there are many empirical studies aimed at determining which countries are in MIT in the literature. These studies are mostly of complementary nature, and empirical modeling is used in relatively few studies. The majority of the studies in question take into consideration factors compatible with empirical modeling such as income thresholds, years passed in the middle income level, determinants of growth slowdowns, determinants of high growth rates, and convergence of the income level of the country with high-income countries (HICs).

Based on the first three cases, Eichengreen et al. (2012) studied growth slowdowns ${ }^{[2]}$ in the period spanning from 1957 to 2007 and tried to determine countries stuck in MIT. The authors underlined the failure of human capital to attain an adequate level, the low share of high-technology products in exports, and the low domestic savings in order to explain growth slowdowns. According to Eichengreen et al (2012), the following conditions are required to

${ }^{[2]}$ The income ranges where growth slowdown occurs are \$10,000-11,000 and \$15,000-16,000 (2005, constant). 
indicate whether a country is in MIT: the average growth rate of the country is $3.5 \%$ or higher in the 7-year period prior to the growth slowdown, a slowdown by minimum $2 \%$ in the growth rate occurs in the following 7-year time period, and the national income per capita of the country is at least $\$ 10,000$ (with 2005 constant prices). Under these circumstances, the researchers stated that 182 instances of growth slowdown indicate MIT. Furthermore, these growth slowdowns occurred mainly in Europe and Latin America (LA). In their studies, the authors particularly emphasize the significance of human capital accumulation and higher education in order to avoid growth slowdown problem.

In another study, Felipe et al. (2012) calculated the number of years in the middle income $^{[3]}$ level along with the growth rates necessary to get out of it. According to their income classification, while 39 countries were at the middle-income level in 1950, a total of 52 countries (38 at the upper-middle level and 14 at the lower-middle level) were at the middleincome level in 2010. The authors claimed that remaining at the lower-middle income level for 28 years or longer and staying at the upper-income level for 14 years or longer indicates MIT. As far as this assumption is concerned, 35 out of 52 MICs (30 in a lower and 5 in a higher) are in MIT. Within the scope of the study, the growth rates needed to be attained by lower- and upper MICs in order to get out of MIT were put forward as $4.7 \%$ and 3.5\%, respectively. The significance of the number of high-quality products within the export composition and the product variety for attaining high growth rates is underlined in the study.

Aiyar et al. (2013) tried to determine countries stuck in MIT by focusing on 123 instances of growth slowdown between 1955 and 2009. They analyzed the impact of 42 indicators and seven determinants (institutions, demographics, infrastructure, macroeconomic environment and politics, commercial structure, output composition, and communication network) on the growth slowdown using probit regression methods. The detailed map of traps given in the study indicates that the effect of these factors on growth vary from one country to another. Another conclusion of the study is that instances of growth slowdown occurred mainly in LA (30), Middle East and North Africa (MENA, 14), East Asia (EA, 9), and sub-Saharan Africa (SSA, 9) regions. In their study, Aiyar et al. (2013) drew attention to regional differences and emphasized that, for all countries, institutions, demographics, infrastructure, and commercial structure play important roles in getting out of MIT.

According to the World Bank report (2013) titled "China 2030: Building a Modern, Harmonious, and Creative Society," only 13 out of 101 countries $^{[4]}$ at the middle-income level in 1960 were able to attain a high-income level. The remaining 88 countries are MICs stuck between $5.5 \%$ and $44 \%$ of the US income per capita. In addition, the report shows that most of MIT countries are in LA and Asia regions.

In their study making use of data from 1960-2009 and concentrating on the 41 countries at the middle-income level in 1960, Bulman et al. (2014) stated that only 10 of these countries are MIT escapees while 24 countries are non-escapees. ${ }^{[5]}$ Furthermore, Bulman et al. (2014) emphasized in the study that the common feature of countries capable of attaining high-income levels is that they are rapidly industrialized countries with high total factor productivity (TFP) and low inflation swiftly completing the structural reform process. These countries also have strong export compositions, high-skilled human capital, good macroeconomic governance, and

\footnotetext{
${ }^{[3]}$ The middle-income range is \$2,000-11,750 (constant, 1990, PPP employed).

${ }^{[4]}$ E. Guinea, Greece, Hong Kong, Ireland, Israel, Japan, Mauritius, Portugal, Puerto Rico, South Korea, Singapore, Spain, and Taiwan.

${ }^{[5]}$ Differently from the study of The World Bank (2013), E. Guinea, Israel, Mauritius, and Portugal were not defined as escapees from the MIT.
} 
more egalitarian income distribution. According to the conclusion of the study, LA and Asian countries, in particular, were caught in MIT as they failed to implement these transformations.

In their studies focusing on LA and EA countries, Woo et al. (2012) tried to determine MIT countries for the 1960-2008 period using the catch-up index. ${ }^{[6]}$ In the study, a country was a high-income country if the catch-up index of a country is above 55\%, a MIC if it was between $20 \%$ and $55 \%$, and a low-income country if it was below $20 \%$. The findings of the study suggest that nine countries, ${ }^{[7]}$ in particular, were caught in MIT in different years within the same period. Among these countries, the ones in LA are still in MIT.

In their study classifying 125 countries on the basis of their income per capita (GNI, in dollar terms), Zhuang et al. (2011) concentrated on 28 countries trapped in the middle income level. Using extrapolation, they concluded that 18 out of 28 countries remained at the middle income level for 50 years. The majority (12) of these 18 countries, which can be considered MIT countries, are located in LA.

A number of studies analyze the states of countries relative to MIT by examining the factors having an impact on growth rates. For instance, Carnovale (2012) concentrated on the linkage between income inequalities and MIT. Taking into consideration the transitions between income groups and the duration of these transitions for 22 countries in the period of 1960-2010, 11 countries that were not able to escape from the upper-middle income level to the high-income group were classified as MIT countries. Furthermore, Carnovale emphasized that income inequalities (Gini > 0.40) were high, and ethnic conflicts were intense in the corresponding countries. In a study analyzing the relation between income inequalities and MIT in China, Malaysia, and Thailand within the context of the Kuznets curve hypothesis, Egawa (2013) also concluded that income inequalities decrease growth rates and cause MIT. In another study handling the relation between the TFP and growth rates of 109 countries, $\mathrm{Wu}$ (2014) asserted that one of the reasons underlying growth slowdown is the decline in TFP. In their studies concerning Turkey, Bozkurt et al. (2014) examined the effect of human capital, domestic savings, and TFP while Yavuz (2017) discussed the impact of fiscal policy on GDP per capita. The findings of these studies suggest that human capital, TFP, domestic savings, and fiscal discipline are of great importance in order for a MIC to get out of MIT.

Ye and Robertson $(2016)^{[8]}$ considered 46 countries out of 189 as MICs depending their 2010 GDP per capita levels (constant PPP employed, in dollar terms). Unlike other studies, their research, starting from the idea of convergence, applied a time series analysis taking shortrun dynamics, structural breaks, and the stochastic trend into consideration in order to determine the situation of MICs relative to MIT. Regarding these results of unit root estimation within which structural breaks are disregarded, 26 countries, many of which are in LA, MENA, and EA, are stuck in MIT. As for the results of time trends and stuck in MIR are taken into consideration, only 7 of these 26 countries show clear evidence regarding the existence of MIT.

Many studies conducted after Ye and Robertson (2016) attempted to determine countries in MIT using a similar approach (hereafter YR approach). For example, analyzing the state of 71 MICs relative to MIT taking structural breaks into consideration, Ünlü and Y1ldiz (2018) concluded that 35 out of these are MIT countries. However, unlike the YR approach, their findings show that Turkey is not an MIT country. In their unit root analyses adapting the case of one and/or more structural breaks, Koçak and Bulut (2014), Bozkurt et al

\footnotetext{
${ }^{[6]}$ Catch-up index is calculated by forming a ratio of the per capita income of the country in question to the income per capita in the US.

${ }^{[7]}$ Argentina, Brazil, Chile, Mexico, Venezuela, Malaysia, Taiwan, South Korea, Thailand.

${ }^{[8]}$ The first version of the study was published in 2013 as a working paper.
} 
(2014), Keskingöz and Dilek (2016), Tıraşoğlu and Karasaç (2018), Manga et al (2019) also empirically indicated that Turkey is not a MIT country. Ayala et al. (2013) examined the income convergence of 17 LA countries with US. Their findings suggest that only three countries (Chile, Costa Rica, and Trinidad and Tobago) essentially converge with the US in terms of their GDP per capita.

In their study concentrating on seven emerging market economies, Yavuz-Tiftikçigil et al. (2018) widened the scope of the YR approach with non-linearity ${ }^{[9]}$ and panel data analyses and examined whether these countries are in MIT. Their findings show that all of the E7 countries are not in MIT. In another study employing the convergence approach and panel data analysis, Bozkurt (2014) concluded that 13 out of 28 upper MICs ${ }^{[10]}$ are stuck in MIT. In a study analyzing 15 EA economies with the panel data analysis and growth convergence approach, Ito (2017) concluded that countries follow three different growth convergence paths (low-income, middle-income, and high-income steady states). In addition, empirical findings provide evidence that China shifted from the middle-income convergence path toward the highincome convergence path while the Philippines shifted toward the low-income path and that Thailand is stuck in MIT. Ito (2017) also stressed the significance of economic reforms initiating changes for the transition from the middle-income path to the high-income path.

\section{Methodology and Data}

\section{Methodology}

In the present study, the author follows the convergence approach as proposed by Ye and Robertson (2016) and makes use of a time series analysis to investigate the states of 44 MICs relative to MIT. Fundamentally, the convergence analyses have been used by researchers for a long time as they establish linkages between economic growth theories and empirical analyses. ${ }^{[11]}$ Convergence signifies the case in which poorer countries and regions attain the per capita income level of HICs or regions in time with higher growth rates. As for empirical convergence analyses, they offer evidence for the validation of different convergence claims put forward by two alternative growth theories. The first one is the convergence hypothesis also known as $\beta$-convergence in the literature, developed by the contributions of neoclassical economists like Solow (1956) and Swan (1956). The neoclassical theory asserts under some assumptions whether per capita income will converge with each country's steady state as called "conditional $\beta$-convergence" or with a common steady state so called "absolute $\beta$ convergence" independently of its initial per capita income level. The difference is that while conditional convergence assumes that there are structural and institutional differences between countries such as technology, preferences, institutional structures, and saving rates, absolute convergence supposes that there are no differences in terms of these features. Second, endogenous growth theory (e.g. Lucas, 1988; Romer, 1986) suggests that technological improvement is endogenized, thus, there is no tendency for per capita income levels to converge.

In their study, Ye and Robertson (2016) focus on a reference country to examine the growth path of MICs in order to develop an empirical definition of MIT within the context of the convergence hypothesis of neoclassical theory. The US was considered as the reference country in this study because it is world technological pioneer along with consistent economic

\footnotetext{
${ }^{[9]}$ Empirical analyses take non-linearity into consideration; however, structural breaks are not modeled.

${ }^{[10]}$ Belize, Brazil, Algeria, Gabon, South Africa, Iran, Jamaica, Colombia, Hungary, Peru, Thailand, Tunisia, and Jordan.

[11] See Barro \& Sala-i Martin (1992), Bernard \& Durlauf (1995), Greasley \& Oxley (1997), Li \& Papell (1996), Zeren \& Yılanc1 (2011), Ayala et al. (2013), Karaca (2016), Yılancı \& Canpolat-Gökçe (2020) for a survey.
} 
growth rate. The authors describe the MICs as countries with per capita income up to $40 \%$ of the US per capita income. Ye and Robertson (2016: 174-176) also define convergence as the income differences approaching zero as $t \rightarrow \infty$. The definition of a MIT is as follows: Country $i$ is in a MIT if

$$
\begin{aligned}
& \lim _{m \rightarrow \infty} E\left(x_{i, t+m} / I_{t}\right)=\bar{x}_{i} \quad \text { and } \\
& \underline{y}_{r, t}-y_{r, t}<\bar{x}_{i}<\bar{y}_{r, t}-y_{r, t}
\end{aligned}
$$

Where, $I_{t}$ represents the information set at time $t, \bar{x}_{i}$ is a non-zero constant, and $\underline{y}_{r, t}$ and $\bar{y}_{r, t}$ are the per capita income bounds that define MIR. Income difference series of the countries can be defined as follows:

$$
x_{i, t}=y_{i, t}-y_{r, t}
$$

Where, $y_{i, t}$ and $y_{r, t}$ are the natural logarithm of $i$ 's and the US' per capita income in year $t$, respectively. As stated in equation (1) and (2), the authors concentrated on the linkage between $y_{i, t}$ and $y_{r, t}$ to determine whether countries are in MIT. The main assumption here is that countries must have the same growth path regarding the growth rate and the income level. Two conditions are required to claim a MIC to be in MIT. First, the equilibrium value of $x_{i, t}$ is expected to be a non-zero constant. The second condition is that the per-capita income of a MIC relative to the US is time-invariant and exists within the MIR.

To examine the existence of these two conditions, the authors employ time series analysis. The validity of the first condition is examined by unit root tests such as Bernard \& Durlauf (1995), Greasley \& Oxley (1997), and Li \& Papell (1999). $x_{i, t}$ must be stationary with a non-zero mean. If a country's $x_{i, t}$ series has unit root, it is characterized as stochastic convergence, indicating that the income gap tends to decrease. For the second condition to be met, the trend estimated for the series $x_{i, t}$ in the unit root models must be statistically insignificant and the mean $\left(\bar{x}_{i}\right)^{[12]}$ of the series $x_{i, t}$ must be within the range of the middleincome band. ${ }^{[13]}$ The time trend coefficient refers to a MIC's speed of convergence or divergence. A positive time trend indicates that the income difference between a MIC and the US will decrease over time. A negative time trend indicates that the income difference will increase over time. The authors consider countries' convergence or divergence tendency as an indicator for escaping from the MIR to the high-income or low-income levels.

In their time series analysis to investigate the existence of MIT in 46 MICs, Ye and Robertson (2016) first examined the stationary $x_{i, t}$ series using the Augmented Dickey-Fuller (ADF). The results of the ADF showed that 20 countries, where the unit root hypothesis cannot be rejected, and 19 countries that have a significant time trend, are not candidates for MIT. They used additional unit root tests to investigate the series of the remaining seven MIT candidate countries. The tests used to analyse the stationarity of the series of the seven countries include the robust-ADF, ZA unit root test with a single structural break (Zivot \& Andrews, 1992), and LP unit root test with two structural breaks (Lumsdaine \& Pappell, 1997). The results of the empirical analysis provided strong evidence that 7 countries $^{[14]}$ are in a MIT.

This study follows and uses the time series approach proposed by Ye and Robertson (2016) to determine the existence of MIT in the MICs. However, this study investigates the validity of stochastic convergence by taking into account the linearity or non-linearity of

\footnotetext{
${ }^{[12]} \bar{x}_{i}$ is estimated as $\bar{x}_{i}=-\mu / \alpha$. Where $\mu$, is the constant, and $\alpha$, (when $\beta=0$ ) is the estimated coefficient of the unit-root regressions.

${ }^{[14]}$ The middle-income band is calculated as the natural logarithm of 0.08 and 0.36 .

${ }^{[14]}$ These countries are Cuba, Lebanon, Turkey, El Salvador, Thailand, Peru, and Syria.
} 
countries' $\mathrm{x}_{\mathrm{i}, \mathrm{t}}$ series rather than using traditional unit root tests such as ADF. Ye and Robertson (2016) took into consideration one or two structural breaks for certain countries, applied unit root tests, and assumed that structural breaks have a sharp transition. In this study, however, structural breaks are modelled by Fourier approximation, are assumed to have a smooth transition, and the number of breaks are endogenously determined.

Additionally, traditional unit root tests like ADF have two important disadvantages. First, these tests do not take into account structural changes arising from economic and/or political shocks in the analyzed period. The disregard of structural changes causes estimation mistakes and results in the failure of rejecting the null hypotheses underlying the unit root claim. In the methodology of time series, following Perron's (1989) defining structural breaks as external, many unit root tests modeling structural breaks as internal have been developed. Among these unit root tests, there are ones with a single structural break (see Lee \& Strazicich, 2004; Zivot and Andrews, 1992) as well as those modeling two (see Lee \& Strazicich, 2003; Lumsdaine \& Pappell, 1997; Narayan \& Popp, 2010) or more structural breaks (see Carrion-i Silvestre et al., 2009). However, although they allow us to define structural breaks as internal, these tests may have weak test powers due to shortcomings such as the need for a priori information and the assumption of breaks as sharp-shift. In order to circumvent this problem, new generation unit root tests have recently been included in the time series literature taking into consideration the possibility of economic series containing multiple smooth breaks on undefined dates (see Becker et al., 2006; Christopoulos \& Leon-Ledesma, 2010; Enders \& Lee, 2012a, 2012b). The author proposes testing the null hypothesis of unit root that allows gradual structural shifts using a Fourier approximation. Moreover, the second disadvantage of traditional unit root tests is that they disregard the non-linearity of economic series. The application of linear time series methods into unit root estimations fails to grasp the asymmetric and/or time-varying adjustment of macroeconomic variables (Enders \& Granger, 1998; Leybourne et al., 1996).

First, the author employs linearity test suggested by Harvey et al. (2008) to check the non-linearity characteristics of countries' $x_{i, t}$. The model to be used if the time series is assumed to be stationary in this test is as follows:

$$
x_{t}=\beta_{0}+\beta_{1} x_{t-1}+\beta_{2} x_{t-2}^{2}+\beta_{3} x_{t-3}^{3}+\sum_{j=1}^{p} \beta_{4, j} \Delta x_{t-j}+\varepsilon_{t}
$$

where, $\Delta$ is the difference operator while $\mathrm{p}$ is the optimal lag calculated under the condition of determining the number of lags as $p_{\max }=\operatorname{int}\left[8(\mathrm{~T} / 100)^{1 / 4}\right]$. The null hypothesis of the test is linearity $\left(\mathrm{H}_{0, \mathrm{I}(0)}: \beta_{2}=\beta_{3}=0\right)$, and the alternative hypothesis is non-linearity $\left(\mathrm{H}_{1, \mathrm{I}(0)}: \beta_{2} \neq\right.$ 0 and, or $\beta_{3} \neq 0$ ). The Wald statistic $\left(\mathrm{W}_{0}\right)$ for the hypothesis test is calculated as follows:

$$
\mathrm{W}_{0}=\mathrm{T}\left(\mathrm{RSS}_{0}^{\mathrm{r}} / \mathrm{RSS}_{0}^{\mathrm{u}}-1\right)
$$

where, T represents the observations, and $\mathrm{RSS}_{0}^{\mathrm{r}}$ and $\mathrm{RSS}_{0}^{\mathrm{u}}$ represent the residual sum of squares generated by restricted and unrestricted models, respectively. The model to be used under the non-stationary assumption for time series is as follows:

$$
\mathrm{x}_{\mathrm{t}}=\lambda_{1} \Delta \mathrm{x}_{\mathrm{t}-1}+\lambda_{2}\left(\Delta \mathrm{x}_{\mathrm{t}-1}\right)^{2}+\lambda_{3}\left(\Delta \mathrm{x}_{\mathrm{t}-1}\right)^{3}+\sum_{\mathrm{j}=1}^{\mathrm{p}} \lambda_{4, \mathrm{j}} \Delta \mathrm{x}_{\mathrm{t}-\mathrm{j}}+\varepsilon_{\mathrm{t}}
$$

The null hypothesis is linearity $\left(\mathrm{H}_{0, \mathrm{I}(1)}: \lambda_{2}=\lambda_{3}=0\right)$, and the alternative hypothesis is nonlinearity $\left(\mathrm{H}_{1, \mathrm{I}(1)}: \lambda_{2} \neq 0\right.$ and, or $\left.\lambda_{3} \neq 0\right)$. The Wald statistic $\left(\mathrm{W}_{1}\right)$ for testing the hypothesis is calculated as follows:

$$
\mathrm{W}_{1}=\mathrm{T}\left(\mathrm{RSS}_{1}^{\mathrm{r}} / \mathrm{RSS}_{1}^{\mathrm{u}}-1\right)
$$


where, $\mathrm{RSS}_{1}^{\mathrm{r}}$ and $\mathrm{RSS}_{1}^{\mathrm{u}}$ represent the residual sum of squares generated by restricted and unrestricted models, respectively. As the stationarity aspects of time series are not known for sure, a new Wald statistic $\left(\mathrm{W}_{\lambda}\right)$ is calculated using these two Wald statistics as seen in the following equation (8). If the test statistic is greater than the critical values tabulated by Harvey et al. (2008), the null hypothesis is rejected.

$$
\mathrm{W}_{\lambda}=\{1-\lambda\} \mathrm{W}_{0}+\lambda \mathrm{W}_{1}
$$

Second, to test stochastic convergence, based on whether series are linear or non-linear, the Fourier ADF (herafter FADF) test proposed by Enders and Lee (2012b), and the Fourier KSS (hereafter FKSS) test proposed by Christopoulos and Leon-Ledesma (2010) are applied in this same order. Enders and Lee (2012b) have developed an ADF-type unit root test with the Fourier function to approximate the deterministic components of unit root model. The standard linear $\mathrm{ADF}$ equation can be writen as follows:

$$
\Delta x_{t}=\rho x_{t-1}+\alpha_{0}+\sum_{i=1}^{p} \alpha_{i} \Delta x_{t-i}+e_{t}
$$

where, $x_{t}$ is the series concerned. $\rho$ and $\alpha$ are the parameters to be estimated, $p$ is the optimal lag for $\Delta x_{t}$, and $e_{t}$ represents white-noise error terms. Under the null hypothesis, i.e. $\rho=0, x_{t}$ is charactarised as a stationary process. Enders and Lee (2012b) put forwarded using a Fourier function to capture unknown structural breaks in the ADF model. The FADF test statistic $\left(\tau_{D F}\right)$ depends on the following equation:

$$
x_{t}=\rho x_{t}+\alpha_{0}+\gamma_{1} \sin \left(\frac{2 \pi k t}{T}\right)+\gamma_{2} \cos \left(\frac{2 \pi k t}{T}\right)+\sum_{i=1}^{p} \alpha_{i} \Delta x_{t-i}+e_{t}
$$

where, $k$ is the frequency and $\gamma$ represents the parameters for the Fourier approximation, $t$ is the trend, $T$ is the number of observation(s), and $\pi=3.1416$. The FADF statistic $\left(\tau_{D F}\right)$ is the ttest statistic for the null hypothesis of $\rho=0$ shown in Equation (9).

The comparison of the two tests shows that the standard ADF is a specific case of the FADF in which trigonometric components are taken as zero (i.e. $\gamma_{1}=\gamma_{2}=0$ ). According to Enders and Lee (2012b), the standard F-test can be used to test whether trigonometric compenents need to be included in the model. Under the null hypothesis of linearity, the Fstatistic can be calculated as follows:

$$
F(k)=\frac{\left(S S R_{0}-S S R_{1}\right) / q}{S S R_{1}(k) /(T-k)}
$$

where, $S S R_{1}$ is the sum of squared residuals (SSR) from the regression of Equation (10), $S S R_{0}$ is the SSR of the regression if there are no trigonometric terms, $q$ is the number of restrictions, and $k$ is the number of regressors. If the null hypothesis of $\gamma_{1}=\gamma_{2}=0$ is rejected, the stationarity of the series $x_{t}$ should be examined with the standard ADF test as trigonometric components are not significant in this case.

In Equation (10), however, the statistic of the FADF is dependent on the number of optimal frequency (k) and optimal lag (p). The optimal frequency (k) is selected by the datadriven method under $k m a x=5$ : it is a selected frequency that produces the smallest SSR among the different specifications in Equation (9). As for the optimal lag, it was determined with the min-t statistic under the maximum lag of 8 .

If the $x_{t}$ series are non-linear, FKSS unit root test proposed by Christopoulos and LeonLedesma (2010) should be applied. FKSS is a 3-stage test procedure (Güriş, 2018; Yılancı \& Eris, 2013). In the first stage, components are defined as shown in the following equations and the residuals are generated with the ordinary least square (OLS) estimation of the equation using the optimal frequency $(\mathrm{k})$ value: 


$$
\begin{aligned}
& \mathrm{x}_{\mathrm{t}}=\alpha_{0}+\gamma_{1} \sin \left(\frac{2 \mathrm{k} \pi \mathrm{t}}{\mathrm{T}}\right)+\gamma_{2} \cos \left(\frac{2 \mathrm{k} \pi \mathrm{t}}{\mathrm{T}}\right)+\mathrm{v}_{\mathrm{t}} \\
& \mathrm{v}_{\mathrm{t}}=\mathrm{x}_{\mathrm{t}}-\alpha_{0}+\gamma_{1} \sin \left(\frac{2 \mathrm{k} \pi \mathrm{t}}{\mathrm{T}}\right)-\gamma_{2} \cos \left(\frac{2 \mathrm{k} \pi \mathrm{t}}{\mathrm{T}}\right)
\end{aligned}
$$

In the second stage, the unit root test is conducted. To that end, the OLS regression estimation of the residual function in the following equation is made, and the t-test statistic is calculated.

$$
\Delta \mathrm{v}_{\mathrm{t}}=\delta_{1} \mathrm{v}_{\mathrm{t}-1}^{3}+\sum_{\mathrm{j}=1}^{\mathrm{p}} \varphi_{\mathrm{j}} \Delta \mathrm{v}_{\mathrm{t}-\mathrm{j}}+\mathrm{u}_{\mathrm{t}}
$$

where, $u_{t}$ is a white noise error term. The unit root null hypothesis, $\left(H_{0}: \delta_{1}=0\right)$, is tested against the non-linear stationary alternative hypothesis $\left(\mathrm{H}_{0}: \delta_{1}<0\right)$ by using the t-test. The critical values corresponding to the frequencies $(\mathrm{k})$ are tabulated in the study conducted by Christopoulos and Leon-Ledesma (2010).

If the unit root is rejected, the null hypothesis of absence of a non-linear trend $\left(\mathrm{H}_{0}: \gamma_{1}=\right.$ $\gamma_{2}=0$, against to $H_{1}: \gamma_{1}=0$ and/or $\left.\gamma_{2} \neq 0\right)$ is tested using F-test, $F(\tilde{\mathrm{k}})$ in the third and final stage. The rejection of the null hypothesis shows that the series is stationary around a breaking deterministic function. The critical values of F-test tabulated by Becker et al. (2006).

Data

The data is the annual natural log of real GDP per capita in 2010 constant prices adjusted dollars for 44 MICs and the US for the period 1960 to 2017. The data is obtained from the World Development Indicator (WDI) dataset provided by the World Bank. When a MIC is defined as $40 \%$ of US per capita income, among 217 countries, 78 countries are categorized as lowincome countries, 73 as MICs, and 50 as HICs according to the 2017 data of the World Bank. No data is available for 16 countries in the WDI dataset. This study samples 44 out of 73 MICs. 13 small-size island countries with a population of less than one million and 16 countries with insufficient observation are excluded from the sample. Table 1 lists the $44 \mathrm{MICs}$ in our sample, defines as the middle 40 per cent of countries ranked by 2010 constant prices (US dollars) in 2017.

Table $1 \quad$ Middle Income Countries

\begin{tabular}{lccccc}
\hline Country & Region & $\begin{array}{c}\text { Real GDP } \\
\text { per capita (2017) }\end{array}$ & $\begin{array}{c}\text { \% of US GDP } \\
\text { per capita }\end{array}$ & Obs. & Period \\
\hline Albania & EU & 4868 & 9.16 & 38 & $1980-2017$ \\
\hline Algeria & MENA & 4825 & 9.08 & 58 & $1960-2017$ \\
Argentina & LA & 10.398 & 19.57 & 58 & $1960-2017$ \\
\hline Bolivia & LA & 6155 & 11.56 & 58 & $1960-2017$ \\
Botswana & SSA & 7523 & 10.47 & 58 & $1960-2017$ \\
Brazil & LA & 10888 & 20.50 & 58 & $1960-2017$ \\
Bulgaria & EU & 8311 & 15.65 & 38 & $1980-2017$ \\
\hline Chile & LA & 15059 & 28.35 & 58 & $1960-2017$ \\
China & AS & 7329 & 13.80 & 58 & $1960-2017$ \\
\hline Colombia & LA & 7600 & 14.31 & 58 & $1960-2017$ \\
Costa Rica & LA & 9791 & 18.43 & 58 & $1960-2017$ \\
Cuba & LA & 6444 & 12.40 & 46 & $1970-2015$ \\
Dominican Rep. & LA & 7153 & 13.46 & 58 & $1960-2017$ \\
\hline Ecuador & LA & 5269 & 9.92 & 58 & $1960-2017$ \\
El Salvador & LA & 7732 & 14.52 & 53 & $1965-2017$ \\
\hline Equatorial Guinea & SSA & 11486 & 21.62 & 38 & $1980-2017$ \\
\hline Fiji & AS & 4663 & 8.88 & 58 & $1960-2017$ \\
\hline Gabon & SSA & 9442 & 17.77 & 58 & $1960-2017$ \\
\hline Georgia & AS & 4290 & 8.08 & 53 & $1965-2017$ \\
\hline
\end{tabular}




\begin{tabular}{|c|c|c|c|c|c|}
\hline Indonesia & AS & 4253 & 8.01 & 58 & $1960-2017$ \\
\hline Iran, Islamic Rep. & MENA & 6946 & 13.08 & 58 & $1960-2017$ \\
\hline Iraq & MENA & 5545 & 10.44 & 50 & $1968-2017$ \\
\hline Jamaica & LA & 4785 & 9.11 & 52 & $1966-2017$ \\
\hline Lebanon & MENA & 7197 & 13.55 & 30 & $1988-2017$ \\
\hline Malaysia & AS & 11521 & 21.69 & 58 & $1960-2017$ \\
\hline Mauritius & SSA & 10186 & 19.17 & 42 & $1976-2017$ \\
\hline Mexico & LA & 9946 & 18.72 & 58 & $1960-2017$ \\
\hline Mongolia & AS & 4271 & 8.04 & 37 & 1981-2017 \\
\hline Namibia & SSA & 9770 & 18.35 & 38 & 1980-2017 \\
\hline Oman & MENA & 16144 & 30.39 & 53 & $1965-2017$ \\
\hline Panama & LA & 11513 & 21.67 & 58 & $1960-2017$ \\
\hline Paraguay & LA & 4296 & 8.08 & 58 & $1960-2017$ \\
\hline Peru & LA & 6172 & 11.62 & 58 & $1960-2017$ \\
\hline South Africa & SSA & 7524 & 14.16 & 58 & $1960-2017$ \\
\hline Sri Lanka & AS & 4311 & 8.11 & 57 & 1961-2017 \\
\hline Swaziland & SSA & 4314 & 8.14 & 48 & $1970-2017$ \\
\hline Suriname & SSA & 8043 & 15.14 & 43 & $1975-2017$ \\
\hline Thailand & AS & 6125 & 11.53 & 58 & $1960-2017$ \\
\hline Trinidad and Tobago & LA & 15350 & 28.89 & 58 & $1960-2017$ \\
\hline Tunisia & MENA & 4303 & 8.18 & 53 & $1965-2017$ \\
\hline Turkey & MENA & 14933 & 28.11 & 58 & $1960-2017$ \\
\hline Turkmenistan & AS & 7317 & 13.77 & 31 & $1987-2017$ \\
\hline Uruguay & LA & 14362 & 27.03 & 58 & $1960-2017$ \\
\hline Venezuela, RB & LA & 13709 & 26.94 & 55 & $1960-2014$ \\
\hline
\end{tabular}

Notes: Data from WDI dataset, GDP per capita with 2010 constant prices. Regions: EU: Europe, AS: Asia and Pacific, MENA: Middle East and North Africa, LA: Latin America, SSA: Sub-Saharan Africa

\section{Empirical Findings}

The author starts the empirical analysis by presenting the linearity test of the variable $x_{i, t}$ for 44 MICs. Table 2 shows the linearity test findings. According to these findings, the test statistics calculated for the series of GDP per capita differences $\left(x_{i, t}\right)$ for 18 countries are greater than the critical values. The linearity hypothesis for the series of these countries is rejected. Therefore, while examining the stationary of the series, 18 countries series necessitate the application of the non-linear FKSS unit root test while the remaining 26 countries' series require employing the linear FADF unit root test.

Table 2 Harvey et al (2008) Linearity Test Results

\begin{tabular}{lcccccc}
\hline Countries & Statistics & $\mathbf{W}_{\mathbf{0}}$ & $\mathbf{W}_{\mathbf{1}}$ & $\boldsymbol{\lambda}$ & $\mathbf{D F}$ & Harris \\
\hline Albania & $13.20^{* * *}$ & 15.1 & 1.60 & 0.14 & -1.22 & -0.28 \\
\hline Algeria & $13.73^{* * *}$ & 0.68 & 18.42 & 0.74 & -1.69 & 0.96 \\
\hline Argentina & 2.82 & 5.83 & 2.48 & 0.90 & -1.59 & 1.54 \\
Bolivia & 4.62 & 3.00 & 4.94 & 0.84 & -1.87 & 1.39 \\
Botswana & $8.29 * *$ & 9.90 & 7.97 & 0.83 & -2.40 & 1.76 \\
Brazil & 5.45 & 7.56 & 3.72 & 0.55 & -2.32 & -0.95 \\
Bulgaria & $6.74 * *$ & 2.18 & 8.31 & 0.74 & -0.87 & -0.51 \\
Chile & 0.88 & 5.67 & 0.84 & 0.99 & -0.35 & 1.22 \\
China & 4.55 & 4.03 & 4.64 & 0.86 & 2.17 & 1.76 \\
Colombia & 3.61 & 1.82 & 4.22 & 0.75 & -1.91 & -1.22 \\
Costa Rica & 1.37 & 0.42 & 2.89 & 0.39 & -2.12 & -0.69 \\
Cuba & 1.11 & 2.14 & 0.18 & 0.55 & -3.06 & -1.26
\end{tabular}




\begin{tabular}{|c|c|c|c|c|c|c|}
\hline Dominican Rep. & $6.18 * *$ & 4.19 & 6.34 & 0.93 & 0.26 & 0.30 \\
\hline Ecuador & 1.23 & 2.85 & 0.97 & 0.86 & -1.85 & 1.52 \\
\hline El Salvador & $8.29 * *$ & 0.98 & 10.24 & 0.79 & -1.94 & 1.26 \\
\hline Equatorial Guinea & $8.58 * *$ & 5.70 & 9.65 & 0.73 & -2.11 & 1.19 \\
\hline Fiji & 1.56 & 0.38 & 1.86 & 0.80 & -1.84 & 1.23 \\
\hline Gabon & $6.56 * *$ & 14.89 & 6.15 & 0.95 & -1.12 & 1.60 \\
\hline Georgia & $10.48 * * *$ & 0.47 & 8.84 & 0.15 & -2.02 & 0.47 \\
\hline Indonesia & $9.09 * *$ & 0.08 & 9.10 & 1.00 & -0.11 & 1.69 \\
\hline Iran, Islamic Rep. & 2.30 & 1.58 & 2.40 & 0.87 & -1.32 & 1.14 \\
\hline Iraq & 3.65 & 2.05 & 4.73 & 0.60 & -3.21 & -1.41 \\
\hline Jamaica & $21.13 * * *$ & 2.11 & 23.1 & 0.91 & -1.33 & 1.34 \\
\hline Lebanon & 4.66 & 2.80 & 6.23 & 0.54 & -3.40 & -1.38 \\
\hline Malaysia & $6.40 * *$ & 1.48 & 6.40 & 1.00 & -0.12 & 1.76 \\
\hline Mauritius & 1.92 & 15.94 & 0.55 & 0.91 & -1.51 & 1.56 \\
\hline Mexico & 1.08 & 0.75 & 1.33 & 0.57 & -3.55 & -1.50 \\
\hline Mongolia & 1.07 & 1.24 & 1.00 & 0.70 & -0.80 & -0.43 \\
\hline Namibia & 0.22 & 0.14 & 2.93 & 0.03 & -2.02 & -0.34 \\
\hline Oman & 5.80 & 5.80 & 15.3 & 0.00 & -1.51 & -0.13 \\
\hline Panama & 4.79 & 3.85 & 5.48 & 0.58 & -1.24 & -0.53 \\
\hline Paraguay & 3.89 & 7.71 & 0.55 & 0.53 & -2.18 & -0.87 \\
\hline Peru & 0.18 & 1.02 & 0.01 & 0.84 & -1.77 & 1.33 \\
\hline South Africa & 1.57 & 3.90 & 1.42 & 0.94 & -1.35 & 1.72 \\
\hline Sri Lanka & 3.13 & 12.53 & 2.82 & 0.97 & 1.02 & 1.79 \\
\hline Swaziland & $6.36 * *$ & 4.15 & 7.81 & 0.60 & -0.88 & -0.39 \\
\hline Suriname & $12.72 * * *$ & 1.87 & 18.95 & 0.64 & -2.69 & 1.26 \\
\hline Thailand & $5.99 * *$ & 2.08 & 6.33 & 0.99 & -0.55 & 1.72 \\
\hline Trinidad and Tobago & $7.43 * *$ & 7.63 & 4.40 & 0.06 & -2.54 & -0.48 \\
\hline Tunisia & $15.90 * * *$ & 0.29 & 20.75 & 0.76 & -1.01 & 0.61 \\
\hline Turkey & $10.16 * * *$ & 10.16 & 6.01 & 0.00 & 0.83 & 0.03 \\
\hline Turkmenistan & 5.37 & 5.31 & 5.40 & 0.67 & -0.98 & -0.49 \\
\hline Uruguay & 0.94 & 0.94 & 0.24 & 0.00 & -1.93 & -0.10 \\
\hline Venezuela, RB & 3.85 & 6.26 & 3.73 & 0.95 & -1.23 & 1.74 \\
\hline
\end{tabular}

Notes: Critical values for the linearity test of Harvey et al. (2008) are -9.21 and -5.99 for statistical significance levels of $1 \%$ and $5 \%$, respectively. $* * *$, and $* *$ indicate $\mathrm{p}<0.01$ and $\mathrm{p}<0.05$, respectively. $\mathrm{W}_{0}$, and $\mathrm{W}_{1}$ signify the Wald statistics calculated in the case that the series are stationary or with a unit root, respectively; $\lambda$ represents weight parameters; DF signifies Dickey-Fuller unit root test statistics.

In the second stage of the analysis, the FADF and FKSS unit root tests are conducted on the countries' $x_{i, t}$ series to test the validity of stochastic convergence. Table 3 shows the unit root test findings for Enders and Lee (2012b) and Christopoulos and Leon-Ledesma (2010). Table 3 also shows the frequency (gradual-shift) numbers and the significance of the trigonometric terms (F-test results). The author finds evidence of stochastic convergence with the US for 21 of the 44 MICs with at least $95 \%$ confidence interval. It is found that there are 21 countries from 44 MICs where the unit root hypothesis cannot be rejected. Details of all results are given in Table 3.

Table 3 Results of FADF and FKSS Unit Root Tests

\begin{tabular}{lccrrrl}
\hline Countries & $\begin{array}{c}\text { Freq. } \\
(\mathbf{k})\end{array}$ & Min. SSR & Fourier ADF & Fourier KSS & F-test & Decision \\
\hline Albania & 1 & 0.2588 & -- & $-0.567(4)$ & -- & Non-MIT \\
Algeria & 2 & 0.2022 & -- & $-3.426 * *(5)$ & $118.5^{* * *}$ & C. of MIT \\
Argentina & 1 & 0.1576 & $-5.139 * * *(7)$ & -- & $13.02 * * *$ & C. of MIT \\
Bolivia & 1 & 0.6662 & $-4.764 * *(8)$ & -- & $23.68 * * *$ & C. of MIT \\
Botswana & 1 & 0.3653 & -- & $-2.245(1)$ & -- & Non-MIT \\
Brazil & 2 & 0.0677 & $-1.939(1)$ & -- & -- & Non-MIT
\end{tabular}




\begin{tabular}{|c|c|c|c|c|c|c|}
\hline Bulgaria & 1 & 0.1511 & -- & $-4.011 * *(1)$ & $68.79 * * *$ & C. of MIT \\
\hline Chile & 4 & 0.0871 & $-1.539(4)$ & -- & -- & Non-MIT \\
\hline China & 1 & 0.1225 & $-2.682(2)$ & -- & -- & Non-MIT \\
\hline Colombia & 3 & 0.0273 & $-1.448(1)$ & -- & -- & Non-MIT \\
\hline Costa Rica & 3 & 0.0233 & $-0.557(1)$ & -- & -- & Non-MIT \\
\hline Cuba & 2 & 0.1130 & $-0.6491(1)$ & -- & -- & Non-MIT \\
\hline Dominican Rep. & 1 & 0.3576 & -- & $-3.396(4)$ & -- & Non-MIT \\
\hline Ecuador & 2 & 0.0581 & $-4.146 * *(6)$ & -- & $14.13 * * *$ & C. of MIT \\
\hline El Salvador & 1 & 0.2836 & -- & $-4.300 * * *(1)$ & $19.55 * * *$ & $\mathrm{C}$ of MIT \\
\hline Equatorial Guinea & 1 & 4.8868 & -- & $-4.030 * *(1)$ & $68.69 * * *$ & C. of MIT \\
\hline Fiji & 1 & 0.0823 & $-4.624 * *(3)$ & -- & $13.64 * * *$ & C. of MIT \\
\hline Gabon & 1 & 1.0689 & -- & $-4.375 * * *(1)$ & $61.0 * *$ & C. of MIT \\
\hline Georgia & 1 & 4.0107 & -- & $-3.666^{* *}(1)$ & $58.85 * * *$ & C. of MIT \\
\hline Indonesia & 2 & 0.3064 & -- & $-5.274 * * *(1)$ & $22.2 * * *$ & C. of MIT \\
\hline Iran, Islamic Rep. & 1 & 0.3913 & $-2.408(1)$ & -- & -- & Non-MIT \\
\hline Iraq & 3 & 1.3912 & $-4.128 * *(0)$ & -- & $12.88 * * *$ & C. of MIT \\
\hline Jamaica & 1 & 1.6668 & -- & $-4.827 * * *(2)$ & $12.66 * * *$ & C. of MIT \\
\hline Lebanon & 2 & 0.2033 & $-3.557(3)$ & -- & -- & Non-MIT \\
\hline Malaysia & 3 & 0.1175 & -- & $-3.753 * * *(3)$ & $21.08 * * *$ & C. of MIT \\
\hline Mauritius & 2 & 0.0273 & $-4.497 * *(7)$ & -- & $11.10 * *$ & C. of MIT \\
\hline Mexico & 3 & 0.0863 & $-3.882 * *(1)$ & -- & $13.68 * * *$ & C. of MIT \\
\hline Mongolia & 1 & 0.0347 & $-4.010(1)$ & -- & -- & Non-MIT \\
\hline Namibia & 1 & 0.0259 & $-3.822(5)$ & -- & -- & Non-MIT \\
\hline Oman & 4 & 0.4094 & $-2.302(5)$ & -- & -- & Non-MIT \\
\hline Panama & 1 & 0.1028 & $-4.408 * *(4)$ & -- & $10.89 * *$ & C. of MIT \\
\hline Paraguay & 2 & 0.0785 & $-1.948(1)$ & -- & -- & Non-MIT \\
\hline Peru & 1 & 0.1176 & $-4.481 * *(1)$ & -- & $11.29 * *$ & C. of MIT \\
\hline South Africa & 1 & 0.0320 & $-3.405(7)$ & -- & -- & Non-MIT \\
\hline Sri Lanka & 4 & 0.0281 & $-1.717(0)$ & -- & -- & Non-MIT \\
\hline Swaziland & 3 & 0.1644 & - & $-1.279(2)$ & -- & Non-MIT \\
\hline Suriname & 1 & 0.7145 & -- & $-4.806 * * *(3)$ & $26.50 * * *$ & C. of MIT \\
\hline Thailand & 2 & 0.2319 & -- & $-2.830(1)$ & -- & Non-MIT \\
\hline Trinidad and Tobago & 1 & 1.1240 & -- & $-4.074 * *(3)$ & $38.43 * * *$ & C. of MIT \\
\hline Tunisia & 2 & 0.1262 & -- & $-3.337 * *(0)$ & $28.40 * * *$ & C. of MIT \\
\hline Turkey & 1 & 0.1537 & -- & $-2.783(0)$ & -- & Non-MIT \\
\hline Turkmenistan & 1 & 0.1442 & $-4.446 * *(5)$ & -- & $11.01 * *$ & C. of MIT \\
\hline Uruguay & 3 & 0.0874 & $-1.175(2)$ & -- & -- & Non-MIT \\
\hline Venezuela, RB & 1 & 0.1194 & $-4.645 * *(6)$ & -- & $14.92 * * *$ & C. of MIT \\
\hline
\end{tabular}

Notes: $* * *$ and $* *$ indicate $\mathrm{p}<0.01$ and $\mathrm{p}<0.05$, respectively. $\mathrm{k}=$ number of frequencies, Min SSR=minimum sum of squared residuals. C. of MIT=candidate of middle income trap, Values in parentheses (...) are the optimal lag length. The critical values for the FADF test are $\mathrm{k}=1(-4.95$, and -4.35$) ; \mathrm{k}=2(-4.69$, and -4.05$) ; \mathrm{k}=3(-4.45$, and -3.78$) ; \mathrm{k}=4(-4.29$, and -3.65$)$ for different frequency values and the statistical significance levels of 1\%, and 5\% respectively (Enders and Lee, 2012b, p. 197, Table 1a). The critical values for the FKSS test are $\mathrm{k}=1(-4.14$, and -3.59$) ; \mathrm{k}=2(-3.84$, and -3.25$) ; \mathrm{k}=3(-3.06$, and -2.99$)$ for different frequency values and the statistical significance levels of $1 \%$ and 5\%, respectively (Christopoulos and Leon-Ledesma, 2010, p. 1084, Table 3). The critical values for the F-test are $12.21(1 \%)$ and $9.14(5 \%)$ in FADF test, respectively. The critical values for the F-test are $6.87(1 \%)$, and $4.97(5 \%)$ for the FKSS test, respectively.

For 23 countries where stochastic convergence is not valid because the series $x_{i, t}$ is stationary, their time trends are also examined to obtain if they are statistically significant. Table 4 shows detailed information on all 23 countries. The time trend is not statistically significant for 7 out of 23 countries. For these seven countries (Fiji, Gabon, Iraq, Mexico, Panama, Peru, and Trinidad and Tobago), there is a strong empirical evidence of the existence of MIT. The trends for the remaining 16 countries are statistically significant. Among them, 8 countries have a positive and the others have a negative time trend. 
Table 4 Time Trends of MIT Candidate Countries

\begin{tabular}{|c|c|c|c|c|c|c|c|c|c|}
\hline \multirow{2}{*}{ Countries } & \multirow{2}{*}{ Obs } & \multirow{2}{*}{ Test } & \multirow{2}{*}{$\gamma_{1}$} & \multirow{2}{*}{$\gamma_{2}$} & \multirow{2}{*}{ Trend } & \multirow{2}{*}{ Statistic } & \multicolumn{2}{|c|}{ Duration } & \multirow{2}{*}{ Decision } \\
\hline & & & & & & & Up. & Low. & \\
\hline Algeria & 58 & 2 & -0.116 & 0.063 & -0.0099 & $-12.0 * * *$ & -- & 13 & Non-MIT \\
\hline Argentina & 58 & 1 & 0.171 & 0.063 & -0.0067 & $-4.30 * * *$ & -- & 133 & Non-MIT \\
\hline Bolivia & 58 & 1 & 0.130 & 0.070 & -0.0051 & $-4.68 * * *$ & -- & 72 & Non-MIT \\
\hline Bulgaria & 37 & 2 & 0.014 & 0.191 & 0.0078 & $4.90 * * *$ & 124 & -- & Non-MIT \\
\hline Ecuador & 58 & 1 & -0.023 & 0.024 & -0.0037 & $-3.70 * * *$ & -- & 57 & Non-MIT \\
\hline El Salvador & 53 & 2 & 0.045 & 0.183 & -0.0124 & $-10.5 * * *$ & -- & 65 & Non-MIT \\
\hline Equatorial Guinea & 38 & 2 & -1.247 & -0.148 & 0.0461 & $10.8 * * *$ & 14 & -- & Non-MIT \\
\hline Fiji & 58 & 1 & 0.067 & 0.004 & 0.0009 & 0.733 & -- & -- & MIT \\
\hline Gabon & 58 & 2 & 0.319 & -0.229 & -0.0027 & -0.97 & -- & -- & MIT \\
\hline Georgia & 53 & 2 & 0.850 & 0.200 & 0.0129 & $3.19 * * *$ & 125 & -- & Non-MIT \\
\hline Indonesia & 58 & 2 & -0.022 & 0.062 & 0.0132 & $16.4 * * *$ & 122 & -- & Non-MIT \\
\hline Iraq & 50 & 1 & -0.093 & 0.024 & 0.0023 & 1.170 & -- & -- & MIT \\
\hline Jamaica & 43 & 2 & -0.032 & 0.089 & -0.0172 & $-9.82 * * *$ & -- & 7 & Non-MIT \\
\hline Malaysia & 58 & 2 & -0.025 & 0.047 & 0.0184 & $40.0 * * *$ & 34 & -- & Non-MIT \\
\hline Mauritius & 42 & 1 & -0.044 & 0.026 & 0.0231 & $4.58 * * *$ & 32 & -- & Non-MIT \\
\hline Mexico & 58 & 1 & -0.008 & 0.020 & -0.0000 & -0.041 & -- & -- & MIT \\
\hline Panama & 58 & 1 & -0.007 & -0.004 & 0.0004 & 1.186 & -- & -- & MIT \\
\hline Peru & 58 & 1 & 0.099 & 0.082 & -0.0006 & -1.113 & -- & -- & MIT \\
\hline Suriname & 43 & 2 & -0.023 & 0.248 & -0.0149 & $-12.8 * * *$ & -- & 42 & Non-MIT \\
\hline Trinidad and Tobago & 58 & 2 & 0.199 & 0.238 & 0.0051 & 1.58 & -- & -- & MIT \\
\hline Tunisia & 53 & 2 & -0.055 & -0.055 & 0.0062 & $12.0 * * *$ & 259 & -- & Non-MIT \\
\hline Turkmenistan & 31 & 1 & 0.023 & 0.055 & 0.0173 & $4.57 * * *$ & 62 & -- & Non-MIT \\
\hline Venezuela, RB & 55 & 1 & 0115 & 0.017 & -0.0137 & $-4.19 * * *$ & -- & 85 & Non-MIT \\
\hline
\end{tabular}

Notes: $* * *$ and $* *$ indicate $\mathrm{p}<0.01$ and $\mathrm{p}<0.05$, respectively. Model 1 and Model 2 signify the FADF and the FKSS unit root models, respectively. $\gamma_{1}$ and $\gamma_{2}$ are the coefficients of trigonometric terms in the unit root models. Statistics are the estimated tstatistics for the trend coefficients. Up. and Low. refer to the time required to reach the upper and lower limits of the middleincome range, respectively.

The estimated time trend coefficients are very small for most of these countries. The small trend coefficients indicate that the convergence (positive trend) or divergence (negative trend) of these countries to the US per capita income from 2017 requires quite a long time. ${ }^{[15]}$ Due to this, it can be said that this is economically not significant. Based on the estimates, the countries expected to have the earliest transition to the upper-income group include E. Guinea, Mauritius and Malaysia, while the countries expected to have the fastest transition to the lower-income group include Jamaica, Algeria, and Ecuador. The estimated transition time ranges from approximately 7 to 259 years for 16 countries. However, the estimated time is longer than 50 years for most countries (10 out of 16 countries). Therefore, it is possible to make a sceptical assessment that most of these MICs — whose trends are statistically significant — are also MIT countries.

\section{Conclusion}

Although it is a recent addition to the literature, MIT is still a frequently discussed concept. On the one hand, there is no consent regarding a clear definition for MIT. On the other hand, many studies have examined which MICs experience MIT. However, there is not a common approach in the previous studies. The countries stuck in MIT and/or the causes of MIT are analyzed based on factors like income thresholds, number of years spent in the middle-income level, growth slowdown and/or the determinants of growth rates, and convergence with HICs. In this study, previous theoretical approaches and examples of empirical findings regarding the issue have been presented.

\footnotetext{
${ }^{[16]}$ The duration for the countries to get out of the middle-income band is computed as follows: number of years $=[\log (40 \%$ of US per capita income / per capita income of the country $\mathrm{i}) / \log (1+$ trend $)]$ for escaping to the upper income group. Number of years $=[(\log (8 \%$ of US per capita income $) /$ per capita income of the country i) $/ \log (1$-trend)] for falling to the lower income group.
} 
It is possible to come up with certain arguments when theoretical approaches and empirical evidence are evaluated together. First, many MIT countries are located in LA, MENA, and EA. Second, the reason why these countries cannot escape MIT is the growth slowdowns following rapid growth along with their failure to implement the structural transformations required to maintain the former rates of rapid growth. Third, the following conditions are vital for one country to climb out of MIT: increasing the TFP and maintaining comparative advantage in exports ( $\& \& D$, technological advancements, innovation/moving from a technological infrastructure based on imitation, proper infrastructure, communication, and high domestic savings), improving and increasing the human capital accumulation (e.g. demographic changes, quality education); diminishing income inequalities, macroeconomic stability, and sufficient institutional capacity (e.g., democracy, safety of property rights, highquality governance, and perfect market economics).

Furthermore, following the time series approach of Ye and Robertson's (2016), the states of 44 middle-income countries relative to MIT are also researched within the scope of this study. Unlike the previous research, non-linearity in the economic series of countries is taken into consideration in the time series analyses of the present study, and new generation estimation methods like the smooth-transition modeling of structural breaks in the series are employed. The empirical findings show the following results: According to the findings of the unit root tests, among 44 middle-income countries, only twenty one countries' $x_{i, t}$ series including Turkey - has a unit root. The $x_{i, t}$ series of the other twenty three countries were found to be stationary. The time trend of the series of 23 countries are also checked for statistical significance. According to the findings, the trend is statistically insignificant for only 7 countries and statistically significant for 16 countries. According to Ye and Robertson's (2016) empirical definition of MIT based on time series analysis, it can be said that Fiji, Gabon, Iraq, Mexico, Panama, Peru, and Trinidad and Tobago are MIT countries because their $x_{i, t}$ series is stationary and time trends are insignificant. According to this definition, no sufficient evidence of MIT is found for 37 countries, including 21 countries for which the series $x_{i, t}$ has a unit root, and 16 countries for which trends are statistically significant.

In addition, among seven countries that are found to be in MIT in the present study, only Peru is a common country with seven countries in Ye and Robertson (2016). Syria, one of the seven MIT countries in their study, is excluded from the sample of this study because it is not in the MIC according to the 2017 data of the World Bank. Additionally, this study finds MIT evidence for Fiji, and Trinidad and Tobago. In contrast, these countries were not in the sample of Ye and Robertson (2016). The findings of this study show that the other five countries that Ye and Robertson (2016) identified as MIT countries including Cuba, Lebanon, Turkey, El Salvador, and Thailand, are not MIT countries due to the validity of stochastic convergence.

As many previous studies following the similar approach have shown (e.g. Koçak \& Bulut 2014; Bozkurt et al., 2014; Keskingöz \& Dilek, 2016; Tıraşoğlu \& Karasaç 2018; Manga et al., 2019), the unit root findings of the present study also indicate that Turkey is not a MIT country. The stochastic convergence between Turkey and the US is significant and it can be said that the income gap between Turkey and US tends to decrease. Similarly, the stochastic convergence is significant for Cuba, Lebanon, El Salvador, and Thailand. On the contrary, the income differences series of El Salvador is stationary but has a significant trend. The trend coefficient is negative for El Salvador. Thus, the income gap between El Salvador and the US does not tend to decrease.

The findings of this study reveal empirical evidence for only seven countries according to Ye and Robertson's (2016) definition of MIT. However, from a more sceptical point of view, 
they also suggest that many more countries are MIT countries. The estimated trend coefficients for most countries are very small. It requires a long time for many MICs to escape from the MIR. Only 6 countries of 16 are estimated to escape from the MIR earlier than 50 years. As a result of this direction these findings are more consistent with those of Felipe et al. (2012), Zhang et al. (2012), The World Bank (2013), and Bulman et al. (2014), all of which present a rather pessimistic scenario for most of the MICs. Therefore, it can be also asserted that the necessity of wide-range structural reforms in most MICs remains vital.

It is both a practical and useful approach to explain whether a country has a tendency to escape from MIR using time series dynamics regarding the convergence hypothesis of neoclassical theory. However, this approach has some limitations and so does this study that has adopted this approach. First, neoclassical theory assumes that the income distribution in the world will not change and relatively less developed economies will follow the growth path of developed economies and are growing faster than these countries. Second, even if this assumption is realistic, the time series dynamics fail to explain the regional or global developments that underlie the convergence or divergence of countries. Moreover, as Ye and Robertson (2016) stated, the convergence approach omitted the individual dynamics of each country's per-capita income path. 


\section{References}

Acemoglu, D, Aghion, P., and Zilibotti, F. (2006). "Distance to Frontier, Selection, and Economic Growth," Journal of the European Economic Association 4(1): 37-74.

Agénor, P. R., and Canuto, O. (2012). "Middle-Income Growth Traps," The World Bank Policy Research Working Paper, No. 6210. https://doi.org/10.1596/1813-9450-6210.

Agénor, P. R., Canuto, O., and Jelenic, M. (2012). “Avoiding Middle-Income Growth Traps," Economic Premise, Poverty Reduction and Economic Management Network (PREM) No. 98, Washington DC: The World Bank.

Aghion, P., and Howitt, P. (1992). "A Model of Growth Through Creative Destruction," Econometrica, 60(2): 323-351.

Aiyar, S., Duval, R., Puy, D., Wu, Y., and Zhang, L. (2013). "Growth Slowdowns and the Middle-Income Trap,” IMF Working Paper 13/71. Washington DC: IMF.

Aoki, M. (2012). "The Five Phases of Economic Development and Institutional Evolution in China, Japan, and Korea," In Institutions and Comparative Economic Development, M. Aoki, T. Kuran, and G. Roland (Eds), London: Palgrave Macmillan, pp. 13-47

Ayala, A., Cunado, J., and Gil-Alana, L. A. (2013).” Real Convergence: Empirical Evidence For Latin America," Applied Economics, 45(22): 3220-3229.

Barro, R.J. , and Sala-i Martin, X. (1992), “Convergence," Journal of Political Economy, 100(2): 223-251.

Barro, R. J. and Sala-i-Martin, X. (1997). Technological Diffusion, Convergence, and Growth. Journal of Economic Growth 2(1): 1-26.

Becker, R., Enders, W., and Lee, J. (2006). "A Stationarity Test in the Presence of An Unknown Number of Smooth Breaks," Journal of Time Series Analysis, 27(3): 381-409.

Bozkurt, E. (2014). Orta Gelir Tuzağı: Türkiye ve Seçilmiş Gelişmekte Olan Ülkeler Üzerine Bir Araştırma, yayınlanmamış doktora tezi, Atatürk Üniversitesi SBE, Erzurum.

Bozkurt, E., Bedir, S., Özdemir, D.ve Çakmak, E. (2014). "Orta Gelir Tuzağı ve Türkiye Örneği," Maliye Dergisi, No. 167: 22-39.

Bulman, D., Eden, M., and Nguyen, H. (2014). "Transitioning from Low-Income Growth to High Income Growth - Is There A Middle Income Trap?," Policy Research Working Paper No. 7104, Washington DC: The World Bank.

Cai, F. (2012). "Is There A 'Middle-Income Trap'? Theories, Experiences and Relevance to China," China \& World Economy, 20(1): 49-61.

Carnovale, M. (2012). Developing Countries and the Middle-Income Trap: Predetermined to Fall, New York University, Leonard N. Stern School of Business, Bachelor of Science, New York.

Carrion-i-Silvestre, J. L., Kim, D., and Perron, P. (2009). GLS-Based Unit Root Tests with Multiple Structural Breaks under Both the Null and the Alternative Hypotheses," Econometric Theory, 25(6): 1754-1792.

Christopoulos, D. K., and León-Ledesma, M. A. (2010). "Smooth Breaks and Non-Linear Mean Reversion: Post-Bretton Woods Real Exchange Rates," Journal of International Money and Finance, 29(6): 1076-1093. 
Dabus, C., Tohme, F., and Carabello, M. A. (2016). "A Middle Income Trap in A Small Open Economy: Modeling the Argentinean Case," Economic Modeling, No. 53: 436-444.

Enders, W., and Granger, C. W. J. (1998). "Unit-Root Tests and Asymmetric Adjustment with An Example Using The Term Structure of Interest Rates," Journal of Business \& Economic Statistics, 16(3): 304-311.

Enders, W., and Lee, J. (2012a). "A Unit Root Test Using a Fourier Series to Approximate Smooth Breaks," Oxford Bulletin of Economics and Statistics, 74(4): 574-599.

Enders, W., and Lee, J. (2012b). "The Flexible Fourier Form and Dickey-Fuller Type Unit Root Tests," Economics Letters, 117(1): 196-199.

Egawa, A. (2013). "Will Income Inequality Cause a Middle-income Trap in Asia?” Bruegel Working Paper, No. 2013/6. https://core.ac.uk/download/pdf/17733163.pdf.

Eichengreen, B, Park, D and Shin, K. (2012). "When Fast-Growing Economies Slow Down: International Evidence and Implications for China," Asian Economic Papers, 11(1): 42-87.

Felipe, J., Abdon, A., and Kumar, U. (2012). "Tracking the Middle-income Trap: What Is It, Who Is in It, and Why?," Levy Economics Institute of Bard College, Working Paper No. 715. https://www.econstor.eu/bitstream/10419/79487/1/71502471X.pdf.

Flaaen, A., Ghani, E., and Mishra, S. (2013). "How To Avoid Middle Income Traps? Evidence from Malaysia," Policy Research Working Paper No. 6427, Washington DC: The World Bank.

Gill, I. S., and Kharas, H. (2007). An East Asian Renaissance: Ideas for Economic Growth. Washington DC: The World Bank.

Gill, I. S., and Kharas, H. (2015). The Middle-Income Trap Turns Ten, Washington DC: The World Bank.

Glawe, L., and Wagner, H. (2016). "The Middle-Income Trap: Definitions, Theories and Countries Concerned-A Literature Survey," Comparative Economic Studies, 58(4): 507-538.

Greasley, D., and Oxley, L. (1997). "Time-Series Based Tests of the Convergence Hypothesis: Some Positive Results,” Economics Letters, 56(2): 143-147.

Güriş, B. (2018). “A New Nonlinear Unit Root Test with Fourier Function,” Communications in Statistics-Simulation and Computation, 1-7.

Harvey, D. I., Leybourne, S. J., and Xiao, B. (2008). "A Powerful Test for Linearity When the Order of Integration is Unknown," Studies in Nonlinear Dynamics \& Econometrics, 12(3): 124.

Hout, A. V. D. (2014). Escaping The Middle Income Trap: The Importance of Inclusiveness for Further Growth, Erasmus School of Economics, Unpublished Master Thesis, Rotterdam.

Im, F. G., and Rosenblatt, D. (2015). "Middle-Income Traps: A Conceptual and Empirical Survey," Journal of International Commerce, Economies and Policy, 6(3): 1-39.

Ito, T. (2017). "Growth Convergence and the Middle-Income Trap," Asian Development Review, 34(1): 1-27.

Kritayanavaj, B., Woo, K.I., Fangchanda, S., Satthaworasit, V., Chientachakul, A.,and Tummanon, A. (2012). "Breaking Out of Middle Income Trap," Asia-Pacific Housing Journal, 6(20): 90-96.

Jankowska, A., Nagengast, A., and Perea, J. R. (2012). "The Middle-Income Trap: Comparing Asian and Latin American Experiences," OECD Development Centre, Policy Insights No. 96. 
Karaca, O. (2018). “Türkiye'de Bölgesel Yakınsamanın 50 Yılı: Yeni Veri Seti ve 1960-2010 Dönemi Analizi,” Sosyoekonomi, 26(35): 207-228.

Keskingöz, H., and Dilek, S. (2016). "Middle Income Trap and Turkey", The Empirical Economics Letter, 15(7): 656-666.

Kharas, H., and Kohli, H. (2011). "What is the Middle Income Trap, Why do Countries Fall Into it, And How Can it Be Avoided?," Global Journal of Emerging Market Economies, 3(3): 281-289.

Koçak, E. ve Ü. Bulut (2014). “Orta Gelir Tuzağı: Teorik Çerçeve, Ampirik Yaklaşımlar Ve Türkiye Üzerine Ekonometrik Bir Uygulama,” Maliye Dergisi, No. 167: 1-21.

Lee, J., and Strazicich, M. C. (2003). "Minimum Lagrange Multiplier Unit Root Test With Two Structural Breaks," Review of Economics and Statistics, 85(4): 1082-1089.

Lee, J., and Strazicich, M. C. (2004). "Minimum LM Unit Root Test with One Structural Break," Manuscript, Department of Economics, Appalachian State University, 1-16.

Lewis, W. A. (1954). "Economic Development with Unlimited Supplies of Labor," Manchester School of Economic and Social Studies, 22: 139-191.

Leybourne, S. J., McCabe, B. P., and Tremayne, A. R. (1996). "Can Economic Time Series Be Differenced to Stationarity?," Journal of Business \& Economic Statistics, 14(4): 435-446.

Li, Q. and Papell, D. (1999), "Convergence of International Output: Time Series Evidence for 16 Countries," International Review of Economics and Finance, 8 (3): 267-80.

Lucas R. E. (1988). "On The Mechanics of Economic Development," Journal of Monetary Economics, 22: 3-42.

Lumsdaine, R. L., and Papell, D. H. (1997). "Multiple Trend Breaks and The Unit-Root Hypothesis," Review of Economics and Statistics, 79(2): 212-218.

Manga, M., Ballı, E., and Güreşçi, G. (2019). "Orta Gelir Tuzağı: Türkiye Üzerine Ampirik Bir Analiz”, Dumlupınar Üniversitesi Sosyal Bilimler Dergisi, 59: 48-60.

Narayan, P. K., and Popp, S. (2010). "A New Unit Root Test with Two Structural Breaks in Level and Slope at Unknown Time," Journal of Applied Statistics, 37(9): 1425-1438.

Ohno, K. (2009). "Avoiding The Middle-Income Trap: Renovating Industrial Policy Formulation in Vietnam," ASEAN Economic Bulletin, 26(1): 25-43.

Öz, S. (2012), “Orta Gelir Tuzağı”, EAF Politika Notu, 12-06, Ekonomik Araştırma Forumu, İstanbul.

Perron, P. (1989). "The Great Crash, the Oil Price Shock, and the Unit Root Hypothesis," Econometrica: Journal of the Econometric Society, 1361-1401.

Reisen, H. (2011). Ways Round the Middle İncome Trap. http://shiftingwealth.blogspot. com.au/2011/11/ways-round-middleincome-trap.html. (Accessed: 12.02.2018).

Romer, P. M. (1986). "Increasing Returns and Long-Run Growth," Journal of Political Economy, 94: 1002-37.

Rostow, W. W. (1990). The Stages of Economic Growth: A Non-Communist, Manifesto. Cambridge: Cambridge University Press.

Solow, R. (1956). "A Contribution to the Theory of Economic Growth," Quarterly Journal of Economics, 70: 65-94. 
Swan, T. W. (1956). "Economic Growth and Capital Accumulation," Economic Record, 32(63): 334-361

The World Bank (2013). China 2030: Building a Modern, Harmonious, and Creative Society. Development Research Centre of the State Council, the People's Republic of China, Washington, DC: The World Bank.

The World Bank (2016). Country and Lending Groups. https://datahelpdesk. worldbank.org/knowledgebase/articles/906519 (Accessed 15.02.2018).

Thọ, T. V. (2013). "The Middle-Income Trap: Issues for Members of the Association of Southeast Asian Nations," Asian Development Bank Institute Working Paper, No. 421. https://dx.doi.org/10.2139/ssrn.2266239

Tıraşoğlu, M., and Karasaç, F. (2018). "Orta Gelir Tuzağı: Yapısal Kırılmalar Altında E7 Ülkeleri İçin Ampirik Bir İnceleme,” Akademik İncelemeler Dergisi, 13(2): 337-361.

Ünlü, F., ve Yıldız, R. (2018). "Orta Gelir Tuzağının Belirlenmesi: Ekonometrik Analiz," Uluslararası Yönetim İktisat ve Iş̧letme Dergisi, 14(1): 1-20.

Woo, W. T. (2012). "China Meets the Middle-Income Trap: The Large Potholes in the Road to Catching-Up," Journal of Chinese Economic and Business Studies, 10(4): 313-336.

Woo, W.T., Lu, M., Sachs, J. D., and Chen, Z. (2012). A New Economic Growth Engine for China: Escaping the Middle-income Trap by Not Doing More of the Same, London: World Scientific Publishing Company: Singapore and Imperial College Press.

Wu, Y. (2014). "Productivity, Economic Growth and The Middle Income Trap: Implications for China," Frontiers of Economics in China, 9(3): 460-483.

Yavuz, E. (2017). "Maliye Kuramı Bağlamında Türkiye'de Orta Gelir Tuzağı Sorunsalının Analizi," Social Sciences, 12(2): 78-101.

Yavuz-Tiftikçigil, B., Güriş, B., and Yaşgül, Y. S. (2018). "Does Middle Income Trap Exist?: Evidence From Emerging Economies: E7 Countries for 1969-2015," Revista Galega de Economia, 27(1): 145-158.

Ye, L., and Robertson, P. E. (2016). "On the Existence of a Middle-Income Trap," Economic Record, 92(297): 173-189.

Y1lanc1, V., and Eriş, Z. A. (2013). "Purchasing Power Parity in African Countries: Further Evidence from Fourier Unit Root Tests Based On Linear and Nonlinear Models," South African Journal of Economics, 81(1): 20-34.

Y1lanc1, V., Aslan, M., and Özgür, Ö. (2018). "Testing the Validity of PPP Theory for African Countries," Applied Economics Letters, 25(18): 1273-1277.

Y1lanc1, V., and Canpolat-Gökçe, E. (2020). "OECD Ülkelerinde Yakınsama Hipotezini Geçerliliği: Kalıntılarla Genişletilmiş Panel Fourier SURADF Birim Kök Testi," Sosyoekonomi, 26(44): 395-407.

Zeren, F., and Yılanc1, V. (2011). "Türkiye'de Bölgeler Arasi Gelir Yakinsamasi: Rassal Katsayili Panel Veri Analizi Uygulaması,"Business and Economics Research Journal, 2(1): 143-151.

Zhuang, J., Vandenberg, P., and Huang, Y. (2012). "Growing Beyond The Low-Cost Advantage - How the People's Republic of China Can Avoid the Middle-Income Trap?," Asian Development Bank: Mandaluyong City, Philippines. 
Zivot, E., and Andrews, D. W. K. (1992). "Further Evidence on the Great Crash, the Oil-Price Shock, and the Unit-Root Hypothesis," Journal of Business \& Economic Statistics, 10(3): 251270. 